\title{
Mutants of Escherichia coli K12 Sensitive to Acidic pH
}

\author{
By J. BIELECKI, J. HREBENDA AND ZBIGNIEW KWIATKOWSKI* \\ Institute of Microbiology, Warsaw University, Nowy Swiat 67,00064 Warsaw, Poland
}

(Received 3 June 1981; revised 15 April 1982)

\begin{abstract}
Four mutants of Escherichia coli $\mathrm{K} 12$ were isolated on the basis of their sensitivity to pH $5 \cdot 4$. Under non-permissive conditions their growth was reversibly inhibited. At $\mathrm{pH} 7.0$ these mutants showed a highly pleiotropic phenotype, which included altered phage and detergent sensitivities and leakage of periplasmic proteins. The findings suggest a defect in the outer membrane, perhaps in lipopolysaccharide. Two mutants mapped in or near the rfa locus, while the other two were remote from this region.
\end{abstract}

\section{INTRODUCTION}

The cell envelope of Gram-negative bacteria is composed of three layers. The outer and inner (cytoplasmic) membranes are separated by a layer of peptidoglycan. Mutants with defects in their outer membranes have been isolated by different selection techniques: increased sensitivity to small hydrophobic molecules, such as detergents, dyes and drugs (Dame \& Shapiro, 1976; Coleman \& Leive, 1979), resistance to specific phages (Prehm et al., 1976; Picken \& Beacham, 1977), or leakage of periplasmic proteins (Lopes et al., 1972).

In this paper we report the isolation and partial characterization of Escherichia coli mutants sensitive to low $\mathrm{pH}$. The results suggest defect(s) in the outer membrane of the mutants.

\section{METHODS}

Organisms. Escherichia coli K 12 strain KMBL 49 (Rörsh) was used for mutant isolation. Recipient strains for transduction are described in Table 1. The R-core specific bacteriophages used were T3 and T4. Phage K3 has its receptor site in outer membrane protein $\mathrm{A}$. The transducing phage was $\mathrm{P} 1$.

Mutant isolation. KMBL 49 was mutagenized with $N$-methyl- $N^{\prime}$-nitro- $N$-nitrosoguanidine as described by Miller (1972). The bacteria were plated on complete LB medium (Miller, 1972), pH 7.0. The colonies were subsequently replicated to LB plates $\mathrm{pH} 5.4$. The initial $\mathrm{pH}$ of the medium was adjusted by adding appropriate amounts of $1 \%(\mathrm{v} / \mathrm{v}) \mathrm{HCl}$. The plates were incubated at $37^{\circ} \mathrm{C}$ for $24 \mathrm{~h}$. Those colonies that failed to grow at the acidic $\mathrm{pH}$ were selected for further tests. They were next grown aerobically at $37^{\circ} \mathrm{C}$ with rotary shaking in LB medium. Bacterial growth was monitored at $540 \mathrm{~nm}$ at both $\mathrm{pH} 7.0$ and 5.4 .

Bacteriophage and detergent sensitivities. For phage sensitivity the conventional cross-streak test was used. Detergent sensitivity was estimated in plates, $\mathrm{pH} \mathrm{7.0}$, containing $800 \mu \mathrm{g}$ of sodium dodecyl sulphate $\mathrm{I}^{-1}$, a concentration that did not kill the wild-type.

Leakage of ribonuclease I. The method described by Lopes et al. (1972) was used.

Genetic analysis. Transduction with phage P1 was performed as described by Willetts et al. (1969) after preliminary mapping of crosses with different $\mathrm{F}^{\prime}$ donors, which corrected the defect of $\mathrm{pH}$-sensitive recipients.

\section{RESULTS AND DISCUSSION}

Four independently isolated mutants that did not grow at pH 5.4 were: KMBL 49-3, KMBL 49-30, KMBL 49-51 and KMBL 49-63. At pH 7.0 the growth of these mutants was normal. The effect of $\mathrm{pH}$ on the growth of the wild-type and two mutants is shown in Fig. 1 . 


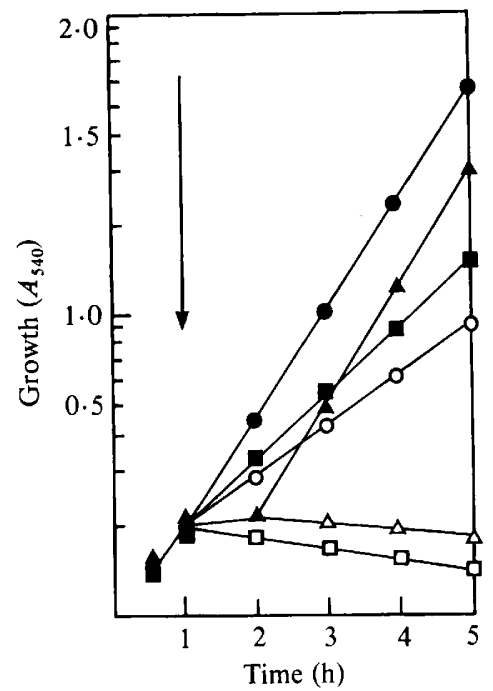

Fig. 1. Growth at pH 5.4 and pH 7.0 of the wild-type strain KMBL 49, and mutants sensitive to acidic $\mathrm{pH}$. Wild-type strain, pH 7.0 (O) and pH $5.4(\mathrm{O})$; strain $\mathrm{KMBL} 49-3, \mathrm{pH} 7.0(\Delta)$ and $\mathrm{pH} 5.4(\Delta)$;

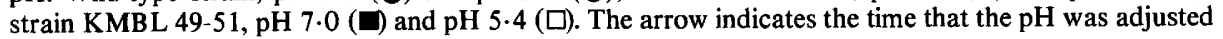
from $7 \cdot 0$ to $5 \cdot 4$.

Table 1. Genetic mapping of mutations conferring sensitivity to acidic $p H$ by P1-mediated transduction

Phage $\mathrm{P1}$ was grown on the $\mathrm{pH}$-sensitive mutants and used to transduce the indicated $\mathrm{pH}$-resistant strains. The transductants, after being purified by single colony isolation, were tested on LB plates, $\mathrm{pH} 5 \cdot 4$.

$\begin{array}{ccccccc}\text { Donor } & \text { Recipient } & \begin{array}{c}\text { Relevant } \\ \text { genotype }\end{array} & \begin{array}{c}\text { Map } \\ \text { position }\end{array} & \begin{array}{c}\text { Selected } \\ \text { marker }\end{array} & \begin{array}{c}\text { Number } \\ \text { scored }\end{array} & \begin{array}{c}\text { Frequency of } \\ \text { pH sensitivity } \\ (\%)\end{array} \\ \text { KMBL 49-3 } & \text { CRT 46 (Hirota) } & \text { ilvB } & 82 & \mathrm{Ilv}^{+} & 600 & 4 \cdot 1 \\ \text { KMBL 49-30 } & \text { CRT 46 (Hirota) } & \text { ilvB } & 82 & \mathrm{Ilv}^{+} & 800 & 10 \cdot 0 \\ \text { KMBL 49-51 } & \text { AB 1157 (Clark) } & \text { galE } & 17 & \mathrm{Gal}^{+} & 800 & 4 \cdot 1 \\ \text { KMBL 49-63 } & \text { JC 5484 (Clark) } & \text { argE } & 89 & \mathrm{Arg}^{+} & 660 & 19 \cdot 0\end{array}$

The effect of low $\mathrm{pH}$ on growth was reversed after readjusting the $\mathrm{pH}$ to $7 \cdot 0$. All the four mutants had the following properties: (1) they were resistant to phages T3 and T4, while retaining their original sensitivity to phage $\mathrm{K} 3 ;(2)$ they had become sensitive to the anionic detergent, sodium dodecyl sulphate; (3) they had started to excrete the periplasmic enzyme, ribonuclease $\mathrm{I}$, into the medium. This combination of properties suggested that they might belong to a group of deep rough mutants defective in their lipopolysaccharide (LPS). However, sensitivity to acidic $\mathrm{pH}$ has not been described previously for LPS mutants.

Preliminary genetic analysis of the mutants, done by mating with different $F^{\prime}$ donors, indicated that three distinct chromosomal locations were involved: the 70-89 min interval for mutations in the strains KMBL 49-3 and KMBL 49-30, the 14-19 min interval for strain KMBL 49-51 and the 87-95 min interval for strain KMBL 49-63.

For more accurate mapping we used phage P1 transduction (Table 1). The mutations in strains KMBL 49-3 and KMBL 49-30 were cotransducible with ilvB at the approximate map position of $82 \mathrm{~min}$. This is the same region as that of the $r f a$ genes $(81 \mathrm{~min})$, which are involved in LPS core biosynthesis (Coleman \& Leive, 1979; Bachmann \& Low, 1980). The 
pH sensitivity of the mutant KMBL 49-51 was weakly linked with galE (at $17 \mathrm{~min}$ ) and that of KMBL 49-63 with $\operatorname{argE}$ (at $89 \mathrm{~min}$ ). There have been no previous reports on mutations at the last two positions which would show changes in the outer membrane structure and function.

This work was supported by a research grant from the Polish Academy of Sciences, Institute of Biochemistry and Biophysics.

\section{REFERENCES}

BachmanN, B. J. \& Low, B. K. (1980). Linkage map of Escherichia coli K12. Edition 6. Microbiological Reviews 44, 1-56.

Coleman, W. \& Leive, L. (1979). Two mutations which affect the barrier function of the Escherichia coli K 12 outer membrane. Journal of Bacteriology 139, 899-910.

Dame, B. J. \& Shapiro, B. M. (1976). Use of polymyxin B, levallorphan, and tetracaine to isolate novel envelope mutants of Escherichia coli. Journal of Bacteriology 27, 961-972.

Lopes, J., GotTFried, S. \& Rothfield, L. (1972). Leakage of periplasmic enzymes by mutants of Escherichia coli and Salmonella typhimurium: isolation of 'periplasmic leaky' mutants. Journal of Bacteriology 109, 520-525.
Miller, J. H. (1972). Experiments in Molecular Genetics. New York: Cold Spring Harbor Laboratory.

Picken, R. N. \& Beacham, I. R. (1977). Bacteriophage-resistant mutants of Escherichia coli K12. Location of receptors within the lipopolysaccharide. Journal of General Microbiology 102, 305-318.

Prehm, P., JANN, B., JanN, K., Schmidt, G. \& Stirm, S. (1976). On a bacteriophage T3 and T4 receptor region within the cell wall lipopolysaccharide of Escherichia coli B. Journal of Molecular Biology 101, 277-281.

Willetts, N. S., Clark, A. J. \& Low, K. B. (1969). Genetic location of certain mutations conferring recombination deficiency in Escherichia coli. Journal of Bacteriology 97, 244-249. 